\title{
PENERAPAN PEMBELAJARAN MODEL-ELICITING ACTIVITIES (MEAS) TERHADAP KEMAMPUAN REPRESENTASI SISWA SMP
}

\author{
THE IMPLEMENTATION OF LEARNING MODEL-ELICITING ACTIVITIES (MEAs) \\ ON REPRESENTATION ABILITY OF ELEMENTARY STUDENTS
}

\author{
Lisa Dwi Afri ${ }^{1}$, Widyastuti² \\ ${ }^{1}$ Pendidikan Matematika, IlmuTarbiyah dan Keguruan, UIN Sumatera Utara Medan \\ ${ }^{2}$ Pendidikan Matematika, Pasca Sarjana, Universitas Pendidikan Indonesia \\ lisadwiafri@uinsu.ac.id
}

\begin{abstract}
Abstrak
Tujuan dari penelitian ini adalah untuk menelaah dan mendeskripsikan pengaruh pembelajaran Model-Eliciting Activities terhadap kemampuan representasi siswa SMP. Selain itu juga ditelaah peningkatan kemampuan representasi ditinjau dari kelompok siswa yaitu kelompok atas dan kelompok bawah. Desain penelitian ini adalah kelompok eksperimen dengan kelompok kontrol pretes dan postes. Kelompok eksperimen memperoleh pembelajaran Model-Eliciting Activities dan kelompok kontrol memperoleh pembelajaran konvensional. Instrumen penelitian berupa tes kemampuan representasi matematis. Populasi penelitian ini adalah seluruh siswa SMP Negeri 25 Bandarlampung dengan sampel penelitian adalah siswa kelas VIII sebanyak dua kelas yang dipilih secara purposif dari tujuh kelas yang ada. Analisis data dilakukan uji perbedaan rerata dua populasi. Hasil penelitian menunjukkan bahwa kemampuan representasi matematis siswa yang memperoleh pembelajaran Model-Eliciting Activities lebih baik daripada siswa yang memperoleh pembelajaran konvensional. Peningkatan kemampuan representasi matematis siswa yang memperoleh pembelajaran ModelEliciting Activities pada kelompok atas maupun pada kelompok bawah secara statistik lebih baik daripada siswa yang memperoleh pembelajaran konvensional.
\end{abstract}

Kata Kunci : Pembelajaran Model-Eliciting Activities, Kemampuan Representasi

\begin{abstract}
The purpose of this study is to examine and describe the effect of learning Model-Eliciting Activities on the representation ability of elementary students. In addition, it was also examined the improvement of representation capabilities in terms of groups of students, namely the upper and lower groups. The design of this study was an experimental group with a pretest and posttest control group. The experimental group obtained learning Model-Eliciting Activities and the control group obtained conventional learning. The instrument was used in the form of a mathematical representation ability test. The population of this study was all students of SMP Negeri 25 Bandarlampung with a sample of research that consisted of two class VIII students purposively selected from seven existing classes. Data had analyzed by a test of the average difference of two populations. The results showed that the mathematical representation ability of students who obtained learning Model-Eliciting Activities was statistically better than students who obtained conventional learning. Increasing the ability of mathematical representation of students who get learning Model-Eliciting Activities in the upper group and in the lower group is statistically better than students who get conventional learning.
\end{abstract}

Keywords: learning Model-Eliciting Activities, Representation 


\section{PENDAHULUAN}

Matematika merupakan ilmu yang kaya, menarik, banyak terkait dengan kehidupan, memungkinkan banyak eksplorasi dan interaksi yang dapat dilakukan siswa. Namun, dalam pembelajaran matematika interaksi yang sering terjadi adalah pemberitahuan definisi dan aturan oleh guru kemudian dilanjutkan dengan demonstrasi pemakaian definisi dan aturan tersebut dalam contoh dan latihan soal.

Hal tersebut didukung oleh Kramarski \& Slettenhaar (Ansari, 2003) yang menyatakan bahwa siswa belajar dengan cara mendengar dan menonoton guru melakukan matematik, guru sering mencotohkan kepada siswa bagaimana menyelesaikan soal dan memberikan soal latihan. Sejalan dengan hal tersebut, Ruseffendi (Ansari, 2003) menyatakan bahwa bagian terbesar dari matematika yang dipelajari siswa di sekolah tidak diperoleh melalui eksplorasi matematika, tetapi melalui pemberitahuan. Pembelajaran yang demikian membuat siswa kurang aktif karena kurang memberi peluang kepada siswa untuk lebih banyak berinteraksi dengan sesama dan dapat membuat siswa memandang matematika sebagai suatu kumpulan aturan dan latihan yang dapat berujung pada rasa bosan dan bingung saat diberikan soal yang berbeda dengan soal latihan.

Hutagaol (2007) menyatakan bahwa terdapatnya permasalahan dalam penyampaian materi pembelajaran matematika, yaitu kurang berkembangnya kemampuan representasi siswa, khususnya pada siswa SMP, siswa tidak pernah diberi kesempatan untuk menghadirkan representasinya sendiri. Lebih jauh Hudiono (2005) menyatakan bahwa siswa yang mengerjakan soal matematika yang berkaitan dengan kemampuan representasi, hanya sebagian kecil siswa dapat menjawab benar, dan sebagian besar lainnya lemah dalam memanfaatkan kemampuan representasi yang dimilikinya khususnya representasi visual.

Untuk mengkomunikasikan ide-ide matematika dan berpikir secara matematis seseorang perlu merepresentasikan ide-ide tersebut dalam cara tertentu. Hal tersebut didukung oleh Hiebert (1990) yang menyatakan bahwa setiap kali mengkomunikasikan gagasan-gagasan matematika, gagasan tersebut perlu disajikan dengan suatu cara tertentu. Hal ini sangat penting agar komunikasi tersebut dapat berlangsung efektif. Komunikasi dalam matematika memerlukan representasi eksternal yang dapat berupa simbol tertulis, gambar, ataupun objek fisik. Ide-ide dalam matematika umumnya dapat direpresentasikan dengan satu atau beberapa jenis representasi.

Representasi yang tepat dapat memberikan pemaknaan terhadap hubungan yang mungkin terjadi di antara berbagai informasi. Penggunaan representasi yang baik akan mampu mengaitkan informasi yang dipelajari dengan kumpulan informasi yang sudah dimiliki siswa. Oleh karena itu, penggunaan representasi mempunyai sumbangan yang sangat besar bagi terbentuknya pemahaman konsep.

Kemampuan representasi seseorang selain menunjukkan tingkat pemahaman, juga terkait erat dengan kemampuan pemecahan masalah dalam penyelesaian tugas matematika. Suatu masalah yang dianggap rumit dan kompleks bisa menjadi lebih sederhana jika strategi dan pemanfaatan representasi matematika yang digunakan sesuai dengan permasalahan tersebut. Sebaliknya, permasalahan menjadi sulit dipecahkan jika penggunaan representasinya keliru. Penggunaan model matematika yang sesuai sebagai suatu bentuk representasi akan membantu pemahaman konsep untuk mengemukakan ide/gagasan matematika siswa.

Salah satu pembelajaran yang menuntut adanya interaksi siswa dalam kelompok adalah pembelajaran Model-Eliciting Activities (MEAs). Pembelajaran MEAs merupakan pembelajaran yang didasarkan pada situasi kehidupan nyata siswa, bekerja dalam kelompok kecil, dan menyajikan sebuah model matematika sebagai solusi.

Sabandar (Hasanah, 2004) menyatakan bahwa munculnya suatu representasi tidaklah terjadi dengan sendirinya dalam situasi yang terisolasi dari situasi atau masalah. Oleh karena itu pemunculan suatu representasi sesungguhnya dapat dipicu atau dirangsang dengan adanya situasi kontekstual, lebih disukai jika siswa akrab dengan situasi tersebut, dan juga memungkinkan siswa menggunakan 
pengetahuan yang diperolehnya secara informal maupun secara formal.

Hal ini sejalan dengan prinsip realitas pembelajaran MEAs yang menyatakan bahwa skenario yang disajikan dalam MEAs sebaiknya realistis dan dapat terjadi dalam kehidupan siswa. Kenyataan merupakan komponen penting dalam MEAs. Menciptakan skenario realistis (berhubungan erat dengan siswa) dapat mencakup konsep abstrak matematika dan meningkatkan rasa tertarik siswa akan masalah. Masalah yang berbentuk word-problem, membutuhkan adanya interpretasi dan representasi dalam bentuk matematika. Proses interpretasi dan representasi ini penting karena memberikan kesempatan untuk melakukan koneksi antar ide-ide matematika terkait.

Dengan memperhatikan uraian di atas, penulis berupaya mengungkapkan apakah pembelajaran Model-Eliciting Activities (MEAs) memberikan kontribusi terhadap kemampuan representasi matematis siswa.

\section{METODE PENELITIAN}

\section{Jenis Penelitian}

Penelitian yang dilakukan merupakan studi kuasi eksperimen. Desain yang digunakan adalah:

$\begin{array}{ll}\text { Kelas Eksperimen } & : \mathrm{O} \\ \text { Kelas Kontrol } & : \mathrm{O}\end{array}$

Keterangan:

$\mathrm{O}$ : Pengukuran kemampuan representasi matematis siswa pada waktu sebelum dan sesudah pembelajaran.

X : Pembelajaran Model-Eliciting Activities (MEAs)

- - - : Subjek tidak dikelompokkan secara acak

\section{Populasi dan Sampel}

Populasi dalam penelitian ini adalah seluruh siswa kelas VIII di salah satu SMP negeri di Bandar Lampung. Sampel terdiri dari dua kelompok siswa kelas VIII yang berasal dari dua kelas yang dipilih secara purposive. Pengambilan sampel secara purposive bertujuan untuk mendapatkan kelas yang memiliki kemampuan awal representasi matematis yang tidak berbeda secara signifikan.
Data, Instrumen, dan Teknik Pengumpulan Data

Data pada penelitian ini adalah hasil pretes dan postes kemampuan representasi matematis. Instrumen yang digunakan meliputi tes kemampuan representasi matematis. Pretes dilakukan pada awal program pembelajaran, postes dilakukan setelah semua materi ajar tentang bangun ruang sisi datar selesai diajarkan.

Data yang diperoleh dari hasil tes diolah melalui tahap-tahap sebagai berikut:

1. Memberikan skor jawaban siswa sesuai dengan kunci jawaban dan sistem penskoran yang digunakan.

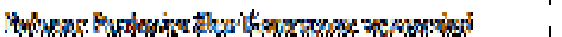

\begin{tabular}{|c|c|c|c|}
\hline Fos & 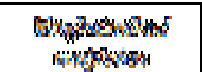 & 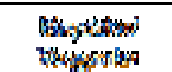 & 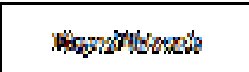 \\
\hline 8 & \multicolumn{3}{|c|}{ 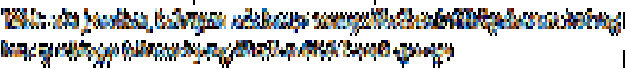 } \\
\hline$\Downarrow$ & 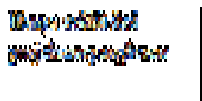 & 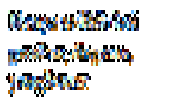 & 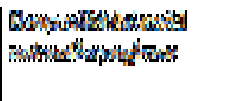 \\
\hline 3 & 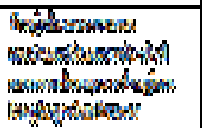 & 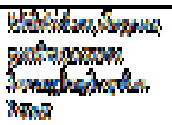 & 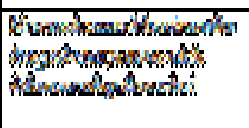 \\
\hline 9 & 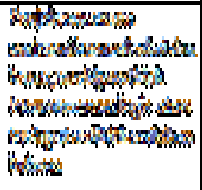 & 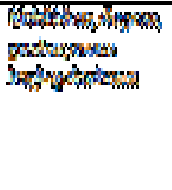 & 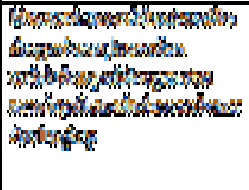 \\
\hline 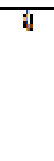 & 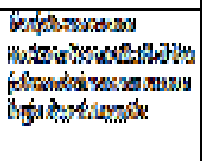 & 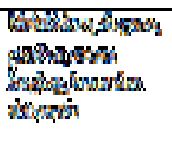 & 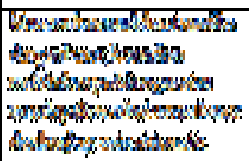 \\
\hline
\end{tabular}

2. Membuat tabel skor pretes dan postes siswa kelas eksperimen dan kelas kontrol.

3. Menghitung peningkatan kemampuan yang terjadi pada siswa kelompok atas dan siswa kelomok bawah dengan rumus gain ternormalisasi, yaitu:

Gain ternormalisasi $(\mathrm{g})=$

skor postes-skor pretes

skor ideal-skor pretes

(Hake, 1999)

Hasil perhitungan gain kemudian

diinterpretasikan dengan menggunakan

klasifikasi sebagai berikut.

Tabel 1. Klasifikasi Gain (g)

\begin{tabular}{|c|c|}
\hline Besarnya Gain (g) & Interpretasi \\
\hline $\mathrm{g} \geq 0,7$ & Tinggi \\
\hline $0,3 \leq \mathrm{g}<0,7$ & Sedang \\
\hline $\mathrm{g}<0,3$ & Rendah \\
\hline
\end{tabular}


4. Melakukan uji normalitas untuk mengetahui kenormalan data skor pretes, skor postes, dan skor gain kemampuan representasi matematis menggunakan uji statistik One-Sample KolmogorovSmirnov.

5. Menguji homogenitas varians tes representasi matematis menggunakan uji Homogeneity of Varians (Levene Statistic).

6. Jika sebaran data normal dan homogen, akan dilakukan uji perbedaan dua rerata. Pengujian ini digunakan untuk menguji perbedaan rerata skor pretes siswa kelompok eksperimen dan kelompok kontrol, skor postes siswa kelompok eksperimen dan kelompok kontrol, dan data gain, dalam hal ini data gain siswa kelompok atas dan kelompok bawah, data gain siswa kelompok atas pada kelompok eksperimen dan kelompok kontrol serta data gain siswa kelompok bawah pada kelompok

\begin{tabular}{|l|l|r|r|r|}
\hline Pembelajaran & $\begin{array}{l}\text { Kategori } \\
\text { Siswa }\end{array}$ & $\begin{array}{c}\text { Rerata } \\
\text { (Mean) }\end{array}$ & $\begin{array}{c}\text { Standar } \\
\text { Deviasi }\end{array}$ & N \\
\hline PMEAs & Atas & 0,5967 & 0,22243 & 9 \\
\cline { 2 - 5 } & Bawah & 0,3922 & 0,11333 & 9 \\
\hline \multirow{2}{*}{ PK } & Atas & 0,2911 & 0,14155 & 9 \\
\cline { 2 - 5 } & Bawah & 0,1956 & 0,14414 & 9 \\
\hline
\end{tabular}

eksperimen dan kelompok kontrol. Uji statistik yang digunakan adalah Compare Mean Independent Samples Test.

Jika datanya tidak berdistribusi normal, maka uji yang dilakukan adalah uji statistik nonparametrik yaitu uji Mann-Whitney.

\section{HASIL PENELITIAN DAN PEMBAHASAN}

Berikut disajikan skor postes kemampuan representasi matematis siswa yang memperoleh pembelajaran ModelEliciting Activities (MEAs) dan siswa yang memperoleh pembelajaran konvensional.

\section{Tabel 2. Data Postes Kemampuan Representasi}

Tabel 2 menunjukkan bahwa, rerata hasil postes pada kelompok eksperimen dan kelompok kontrol memiliki perbedaan. Persentase skor kelompok eksperimen 14,92\% lebih tinggi daripada kelompok kontrol. Keberartian perbedaan itu dibuktikan dengan uji perbedaan rataan, dimana diperoleh nilai signifikansi (sig.) sebesar 0,000 lebih kecil dari $\alpha=0,05$. Sehingga dapat disimpulkan bahwa hipotesis nol yang menyatakan tidak terdapat perbedaan rerata kedua kelompok data, ditolak. Berarti kemampuan representasi matematis siswa yang memperoleh pembelajaran MEAs secara statistik lebih baik daripada kemampuan representasi matematis siswa yang memperoleh pembelajaran konvensional.

Berdasarkan analisis data tersebut, diketahui bahwa pembelajaran Model-Eliciting Activities mempunyai pengaruh terhadap kemampuan representasi matematis siswa. Hal ini ditunjukkan dengan adanya perbedaan rerata skor postes kemampuan representasi matematis yang diperoleh siswa pada kelompok eksperimen dan kelompok kontrol setelah proses pembelajaran. Penelitian ini relevan dengan penelitian

Pengaruh pembelajaran MEAs juga dilihat terhadap peningkatan kemampuan representasi matematis pada siswa kelompok atas dan siswa kelompok bawah. Peningkatan yang terjadi diukur dengan menggunakan skor gain siswa kedua kelompok. Berikut adalah data $n$-gain kemampuan representasi matematis.

\section{Tabel 3. Rerata Gain Kemampuan Representasi Matematis}

Berdasarkan Tabel 3. terdapat beberapa kesimpulan yang berkaitan dengan kemampuan representasi matematis yang dapat diungkap, yaitu:

a. Pada PMEAs, rerata gain kemampuan representasi matematis kedua kelompok siswa tergolong ke dalam kategori sedang.

\begin{tabular}{|c|c|c|c|c|c|c|c|}
\hline \multirow{2}{*}{ Kelompok } & \multirow{2}{*}{$\begin{array}{c}\text { Jumlah } \\
\text { Siswa }\end{array}$} & \multirow{2}{*}{$\begin{array}{l}\text { Skor } \\
\text { Ideal }\end{array}$} & \multicolumn{5}{|c|}{ Postes } \\
\hline & & & $x_{\min }$ & $x_{\text {maks }}$ & $\bar{x}$ & $\%$ & $S$ \\
\hline Eksperimen & 32 & \multirow{2}{*}{48} & 10 & 40 & 23,25 & 48,44 & 8,75 \\
\hline Kontrol & 32 & & 3 & 30 & 16,09 & 33,52 & 6,57 \\
\hline
\end{tabular}

Rerata gain kemampuan representasi matematis siswa kelompok atas $(0,5967)$ lebih tinggi dibandingkan dengan rerata gain kemampuan representasi matematis siswa kelompok bawah $(0,3922)$.

b. Untuk siswa kelompok atas, rerata gain kemampuan representasi matematis yang pembelajarannya berdasarkan PMEAs $(0,5967)$ tergolong ke dalam kategori sedang dan lebih tinggi dibandingkan dengan gain kemampuan representasi matematis pembelajaran berdasarkan PK 
$(0,2911)$ yang tergolong ke dalam kategori rendah

c. Untuk siswa kelompok bawah, rerata gain kemampuan representasi matematis yang pembelajarannya berdasarkan PMEAs (0,3922) tergolong ke dalam kategori sedang dan lebih tinggi dibandingkan dengan rerata gain kemampuan representasi matematis pembelajaran berdasarkan PK $(0,1956)$ yang tergolong ke dalam kategori rendah

Untuk mengetahui signifikansi kebenaran kesimpulan di atas perlu dilakukan perhitungan pengujian statistik dengan menggunakan uji perbedaan rerata dua populasi. Berdasarkan hasil analisis skor gain, diketahui bahwa rerata gain siswa kelompok atas dan rerata gain siswa kelompok bawah yang memperoleh pembelajaran MEAs tergolong ke dalam kategori sedang menandakan bahwa peningkatan kemampuan representasi matematis terjadi belum pada semua indikator. Jika memperhatikan rerata hasil tes representasi matematis siswa kelompok eksperimen dan kelompok kontrol, diketahui bahwa kemampuan representasi yang terkait dengan aspek representasi visual dan aspek representasi dengan kata-kata pada siswa yang memperoleh pembelajaran MEAs menunjukkan peningkatan yang lebih baik daripada siswa yang memperoleh pembelajaran konvensional. Untuk kemampuan representasi matematis yang terkait dengan aspek persamaan matematis, antara kelompok kontrol dan kelompok eksperimen peningkatan yang terjadi tidak terlalu berbeda.

Hasil analisis juga menunjukkan bahwa peningkatan kemampuan representasi matematis siswa kelompok atas lebih baik daripada peningkatan kemampuan representasi matematis siswa kelompok bawah. Peningkatan kemampuan representasi matematis siswa kelompok atas pada kelompok eksperimen lebih baik daripada kelompok kontrol. Begitu juga dengan peningkatan kemampuan representasi matematis siswa kelompok bawah pada kelompok eksperimen lebih baik daripada kelompok kontrol. Berarti, pembelajaran Model-Eliciting Activities mempunyai pengaruh terhadap peningkatan kemampuan representasi matematis siswa.
Pada penelitian ini, hal-hal yang mendukung bahwa kemampuan representasi matematis siswa yang memperoleh pembelajaran Model-Eliciting Activities lebih baik daripada siswa yang memperoleh pembelajaran konvensional, salah satunya adalah karena siswa pada kelompok eksperimen terbiasa membuat model matematis sebagai solusi dari permasalahan MEA yang diberikan dimana model matematis merupakan salah satu bentuk representasi matematis. Hal lainnya adalah karena siswa pada kelompok eksperimen dituntut untuk melakukan kegiatan presentasi. Pada kegiatan presentasi ini, siswa dituntut untuk mempresentasikan hasil kerja dan pemikiran mereka. Siswa kelompok eksperimen dituntut untuk menyatakan prosedur yang mereka lalui untuk mendapatkan solusi permasalahan MEA yang diberikan sehingga terjadi proses representasi kata-kata. Mereka juga mengalami tahap pembelajaran pertanyaan siap-siaga, dimana pada tahap ini guru memberikan pertanyaan kepada siswa untuk memastikan bahwa siswa telah memiliki pengetahuan dasar yang mereka perlukan untuk menyelesaikan permasalahan. Pertanyaanpertanyaan juga dikemukakan oleh guru dan siswa lainnya pada saat kegiatan presentasi. Pertanyaan yang diajukan mencakup tentang kebenaran konsep dan kebenaran ide yang mereka miliki. Adanya kegiatan presentasi dimana hasil kerja siswa diminta pertanggungjawabannya membuat siswa kelompok eksperimen terbiasa merepresentasikan ide-idenya dengan menggunakan kata-kata. Tugas MEAs yang menuntut adanya generalisasi dari model yang siswa sajikan sebagai solusi permasalahan membuat siswa terbiasa membuat prosedur dan mengajikan prosedur tersebut dalam rangkaian kata-kata sehingga kemampuan siswa kelompok eksperimen dalam hal representasi kata-kata menjadi lebih baik. Adanya diskusi kelompok memfasilitasi terjadinya proses transfer ide dan komunikasi antara sesama anggota kelompok, sesama teman dan dengan guru dimana proses ini menuntut siswa untuk memperbaiki kemampuannya dalam merepresentasikan ideide matematika yang mereka miliki agar dapat lebih mudah dipahami orang lain. 
Kelebihan lainnya dari siswa kelompok eksperimen (memperoleh pembelajaran MEAs) dibandingkan dengan kelompok kontrol (memperoleh pembelajaran konvensional) adalah dalam menuangkan ide matematika dalam bentuk representasi gambar. Siswa kelompok eksperimen terbiasa menggunakan prosedur matematis yang telah mereka pelajari untuk diterapkan dalam rangka menyelesaikan permasalahan yang diberikan. Siswa juga terbiasa mengaitkan pengalaman nyata dalam kehidupan sehari dengan konsep matematika yang telah mereka miliki. Mereka juga berpikir lebih kreatif dan lebih kritis dalam menghakimi ide-ide serta pemikiran mereka. Siswa kelompok eksperimen lebih berani menanyakan kepada guru kebenaran ide yang mereka pikirkan. Pembelajaran ini juga membuat siswa kelompok eksperimen mampu berargumen mempertahankan pendapat dan hasil pemikiran mereka. Pembelajaran ini juga membuat siswa untuk memeriksa kembali kebenaran konsep dan ide yang mereka miliki. Pertanyaan "mengapa" yang sering dilontarkan oleh guru baik dalam tahapan pertanyaan siap siaga maupun dalam kegiatan presentasi membuat siswa lebih paham dan lebih menggali potensi dalam diri mereka dalam rangka mencari jawaban apa yang dipertanyakan. Pertanyaan tersebut juga membuat siswa semakin berhatihati dalam berpikir bahkan cenderung takut mengemukakan ide mereka karena takut ditanya "mengapa".

Ketika siswa mengalami kebuntuan dalam menyelesaikan permasalahan yang diberikan, siswa diarahkan untuk melakukan pengamatan dan mencari informasi-informasi penting pada buku-buku sumber yang berkaitan dengan permasalahan yang sedang dihadapi. Siswa diarahkan untuk bertanya dan mendiskusikan permasalahan tersebut kepada teman sekelompoknya atau teman pada kelompok lain terlebih dahulu. Adanya kegiatan diskusi kelompok memungkinkan siswa untuk saling berinteraksi satu sama lain, bertanya, menyampaikan pendapat, dan menanggapi pendapat siswa lain. Ketika siswa masih megalami kebuntuan, guru mengarahkan siswa melalui pertanyaan-pertanyaan bimbingan (teknik scaffolding). Di dalam hal ini, guru tidak menjawab langsung pertanyaan siswa dan lebih berperan sebagai fasilitator dalam belajar. Siswa harus melewati keseluruhan proses ini hingga akhirnya siswa dapat menemukan sendiri penyelesaian dari permasalahan yang diberikan.

\section{KESIMPULAN}

Berdasarkan hasil penelitian, diperoleh beberapa kesimpulan sebagai berikut.

1. Kemampuan representasi matematis kelompok siswa yang memperoleh pembelajaran Model-Eliciting Activities (MEAs) lebih baik dari kelompok siswa yang memperoleh pembelajaran konvensional.

2. Peningkatan kemampuan representasi matematis siswa kelompok atas dan siswa kelompok bawah pada kelompok siswa yang memperoleh pembelajaran ModelEliciting Activities berada pada kategori sedang dimana peningkatan kemampuan representasi siswa kelompok atas lebih baik daripada peningkatan kemampuan representasi matematis siswa kelompok bawah.

3. Siswa kelompok atas yang memperoleh pembelajaran Model-Eliciting Activities (MEAs) mengalami peningkatan kemampuan representasi matematis yang lebih baik daripada siswa kelompok atas yang memperoleh pembelajaran konvensional.

4. Siswa kelompok bawah yang memperoleh pembelajaran Model-Eliciting Activities (MEAs) mengalami peningkatan kemampuan representasi matematis yang lebih baik daripada siswa kelompok bawah yang memperoleh pembelajaran konvensional.

\section{DAFTAR PUSTAKA}

Ansari, B.I. (2003). Menumbuhkembangkan Kemampuan Pemahaman dan Komunikasi Matematis Siswa SMU Melalui Strategi ThinkTalk-Write. Disertasi. UPI: Tidak diterbitkan.

As'ari, A. (2001). Representasi: Pentingnya dalam Pembelajaran Matematika. Jurnal Matematika atau Pembelajarannya. 2, 81-91.

Dewanto, S. P. (2007). Meningkatkan Kemampuan Representasi Multipel Matematis Mahasiswa Melalui Belajar 
Berbasis-Masalah. Disertasi. UPI: Tidak diterbitkan.

Diefes-Dux, H.A., Salim, A. (2009). Problem Formulation during Model-Eliciting Activities: Characterization of FirstYear Student's Responses. Proceeding of the Research in Engineering Symposium 2009, Palm Cove, QLD.

Diefes-Dux, H.A., Verleger, M. A. (2009). Student Reflections on Peer Reviewing Solutions to Model-Aliciting Activities.

Eric, C. C. M. (2008). Using Model-Eliciting Activities for Primary Mathematics Classrooms. The Mathematics Educator, Vol. 11, No. 1/2, 47-66.

Hake, R.R. (1999). Analyzing Change/Gain Scores. [Online]. Tersedia: http://www.physics.indiana.edu/ sdi/An alyzingchange-Gain.pdf.

Hall, C. S., Lindzey, G., dan Campbell, J. B. (1998). Theories of Personality. Third Edition. New York: John Willey and Sons, Inc.

Hasanah, A. (2004). Mengembangkan Kemampuan Pemahaman dan Penalaran Matematik Siswa Sekolah Menengah Pertama Melalui Pembelajaran Berbasis Masalah yang Menekankan pada Representasi Matematik. Tesis. UPI: Tidak diterbitkan.

Hill, W.F. (2009). Theories of Learning: Konsepsi, Komparasi, dan Signifikansi. Bandung: Nusa Media.

Hjalmarson, M. A., Diefes-Dux, H. Teacher as Designer: A Framework for Teacher Analysis of Mathematical ModelEliciting Activities. The Interdisciplinary Journal of Problembased Learning, Vol. 2, No. 1, pp. 57-78.

Hudiono, B. (2005). Peran Pembelajaran Diskursus Multi Representasi terhadap Pengembangan Kemampuan Matematik dan Daya Representasi pada Siswa SLTP. Disertasi. UPI: Tidak diterbitkan.

Hutabarat, D. (2009). Studi Perbandingan Kemampuan Penalaran dan Representasi Matematis pada Kelompok Siswa yang Belajar Inkuiri dan Biasa. Tesis. UPI: Tidak
Hutagaol, K. (2007). Pembelajaran Matematika Kontekstual untuk Meningkatkan Kemampuan Representasi Matematis Siswa Sekolah Menengah Pertama. Tesis SPS UPI Bandung: Tidak diterbitkan.

Indriani, Lely. (2008). Pengaruh Penerapan Pembelajaran Matematika Berbasis Multiple Intelegence terhadap Kemampuan Representasi Matematik Siswa. Skripsi. UPI: Tidak diterbitkan.

Lesh, R., Hoover, M., Hole, B., Kelly, A., \& Post, T. (2000). Principles for Developing Thought-Revealing Activities for Students and Teachers. [Online]. Tersedia: http:// www. cehd. umn. edu/ rationalnumberproject/ 00_2.html

Maddy, S. R. (1968). Personality Theories: A Comparative Analysis. Illinois: The Dorsey Press.

Marsh, H.W., Baumert, J., Koller, O. (2001). Reunification of East and West German School Systems: Longitudinal Multilevel Modeling Study of the BigFish-Little-Pond Effect on Academic Self-Concept. American Educational Research Journal. Vol. 38, No. 2, pp. 321-350.

Mulyana, T. (2009). Mencari Pembelajaran yang Sesuai dengan Tuntutan Kurikulum Matematika 2009. Makalah.

NCTM. (2000). Principles and Standards for School Mathematics. Reston, VA: NCTM.

Ruseffendi, H. E. T. (1993). Statistika Dasar untuk Penelitian Pendidikan. Bandung: Departemen Pendidikan dan Kebudayaan. 